\title{
Tingkat Penerimaan Panelis terhadap Yoghurt dengan Perlakuan Lama Fermentasi, Jenis Susu dan Lama Penyimpanan yang Berbeda
}

(Level of Acceptance of panelists Against Yogurt with Fermentation Time, Types of Milk and Different Storage Lengths)

\author{
Tursina $^{1}$ Irfan $^{1}$, Sri Haryani ${ }^{{ }^{*}}$ \\ ${ }^{1}$ Program Studi Teknologi Hasil Pertanian, Fakultas Pertanian, Universitas Syiah Kuala
}

\begin{abstract}
Abstrak: Susu didefinisikan sebagai salah satu bahan pangan bernutrisi tinggi yang baik berperan sebagai asupan penting untuk, pertumbuhan kesehatan dan kecerdasan. Walaupun susu memiliki nilai gizi yang sangat baik namun untuk sebagian orang konsumsi dapat menimbulkan masalah berupa terjadinya lactose intolerance yaitu ketidakmampuan tubuh untuk mencerna laktosa yang terdapat didalam susu. Hal ini dapat diatasi dengan mengubah laktosa menjadi glukosa dan galaktosa dengan cara fermentasi. Salah satu produk fermentasi berbasis susu adalah yoghurt. Penelitian ini bertujuan untuk mempelajari pengaruh lama fermentasi dan jenis susu yang digunakan dalam pembuatan yoghurt terhadap sensori yoghurt selama masa penyimpanan. Penelitian ini dilakukan menggunakan Rancangan Acak Kelompok (RAK) yang terdiri dari 3 faktor, faktor pertama yaitu lama fermentasi (F) yang terdiri dari 2 taraf, yaitu: $F 1=10 \mathrm{jam}, \mathrm{F} 2=16 \mathrm{jam}$. Faktor kedua yaitu jenis susu yang digunakan yang terdiri dari 2 taraf, yaitu: S1 = susu sapi dan S2 = susu kambing. Faktor ketiga yaitu lama penyimpanan yang terdiri dari 3 taraf, yaitu: $\mathrm{P} 1=0$ minggu, $\mathrm{P} 2=2$ minggu, P3 = 4 minggu. Analisis yang dilakukan adalah uji organoleptik secara hedonik meliputi atribut warna, aroma, rasa dan tekstur. Hasil uji organoleptik (hedonik) menunjukkan bahwa secara umum panelis lebih menyukai yoghurt perlakuan jenis susu sapi dengan fermentasi 10 jam dan lama penyimpanan 3 hari (minggu ke-0).
\end{abstract}

Kata kunci: Kualitas, sensori, yoghurt, Streptococcus thermophilus, Lactobacillus bulgaricus.

\begin{abstract}
Milk is determined as one of the high nutritious kind of foods that are good for important consumption, health and intelligence growth. Because milk has a very good nutritional value for most people who can spend problems because of lactose intolerance which is the body's inability to digest lactose in milk. This problem can be overcome by converting lactose to glucose and galactose by fermentation. One of the milk-based fermented products is yogurt. This study aims to investiage the effect of fermentation time and the type of milk used in making yogurt on the sensory yogurt during the storage period. This study was conducted using a Randomized Block Design (RBD) consisting of 3 factors, the first factor was the duration of fermentation (F): F1 $=10$ hours, $\mathrm{F} 2=16$ hours. The second factor was the type of milk used which consists of two levels, namely: $\mathrm{S} 1=$ cow's milk and $\mathrm{S} 2=$ goat's milk. The third factor is the storage time which we: P1 $=0$ weeks, $\mathrm{P} 2=2$ weeks, $\mathrm{P} 3=4$ weeks. The analysis carried out were a hedonic test covering attributes of color, aroma, taste and texture. The organoleptic (hedonic) test results showed that in general all panelists preferred yogurt which was made by cow milk with 10 hours fermentation and 3 days of storage time (week 0).
\end{abstract}

Keywords: Quality, sensory, yoghurt, Streptococcus thermophilus, Lactobacillus bulgaricus.

\section{PENDAHULUAN}

Susu merupakan cairan berwarna putih yang berperan sebagai asupan nutrisi bagi pertumbuhan, kesehatan dan kecerdasan. Susilowati (2012), menyatakan bahwa susu mengandung air sekitar 87,5\% dengan komposisi gula susu berkisar 5\%, lemak sekitar 3 sampai $4 \%$ dan protein 3,5\%. Zakaria et al (2013) menambahkan susu juga mengandung kalsium, fosfor dan vitamin A yang sangat baik. Selain itu susu juga kaya akan kandungan lisin yaitu salah satu asam amino essensial yang sangat diperlukan oleh tubuh. 
Walaupun susu memiliki nilai gizi yang sangat baik namun untuk sebagian orang konsumsi dapat menimbulkan masalah berupa terjadinya lactose intolerance yang merupakan ketidakmampuan tubuh untuk mencerna laktosa yang terdapat didalam susu. Hal ini dapat diatasi dengan mengubah laktosa menjadi glukosa dan galaktosa dengan cara fermentasi. Salah satu produk olahan berbasis susu terfermentasi ialah yoghurt. Yoghurt merupakan minuman probiotik hasil fermentasi susu dengan penambahan kultur dan memiliki rasa dan aroma yang khas. Yoghurt dapat diolah dengan berbagai jenis susu seperti susu kambing, susu sapi dan susu kedelai (Widodo, 2002).

Jenis dan jumlah starter yang ditambahkan dalam pembuatan yoghurt berpengaruh terhadap kualitas akhir produk (Hafsah dan Astriana, 2012). Pada umumnya starter yang dimanfaatkan dalam proses pembuatan yoghurt ialah Lactobacillus bulgaricus dan Streptococcus thermophilus dengan perbandingan optimum 1 : 1 (Layadi et al., 2009). Keseimbangan kedua bakteri dapat dipertahankan dengan mengatur suhu dan persentase kulturnya, dimana persentase terbaik berkisar antara 2-5\% (Tamime dan Robinson, 2000).

Lama fermentasi dan jenis susu juga berpengaruh terhadap karakteritik yoghurt yang dihasilkan. Fatmawati et al (2013) mengemukakan, yoghurt yang dibuat dari berbagai jenis susu (susu kedelai, susu kambing, susu sapi segar, susu skim nabatidan susu UHT) yang di fermentasi selama 15 jam pada suhu $37^{\circ} \mathrm{C}$ berpengaruh terhadap kadar asam laktat, jumlah mikroba total asam laktat dan $\mathrm{pH}$ yoghurt dengan masa simpan 14 hari.

Menurut Effendi et al (2009), kosentrasi susu skim dan lama fermentasi dalam pembuatan yoghurt dari susu kambing berpengaruh terhadap organoleptik yoghurt. Yoghurt yang difermentasi pada suhu $40^{\circ} \mathrm{C}$ selama 6 sampai 8 jam menghasilkan karakteristik yoghurt yang lebih baik dari pada fermentasi yoghurt pada suhu ruang selama 10 sampai 12 jam. Candraningtyastuti (2016) menambahkan, fermentasi yoghurt dapat dilakukan pada suhu ruang atau pada suhu $45^{\circ} \mathrm{C}$ dengan waktu fermentasi yang berbeda. Inkubasi pada suhu ruang memerlukan waktu lebih lama dari pada inkubasi pada suhu $45^{\circ} \mathrm{C}$ yaitu 14 sampai 16 jam, sedangkan inkubasi pada suhu $45^{\circ} \mathrm{C}$ hanya memerlukan waktu 4 sampai 6 jam fermentasi.

Penyimpanan yang terlalu lama dapat membuat yoghurt mengalami kerusakan fisik berupa terpisahnya yoghurt. Hal ini dikarenakan penurunan $\mathrm{pH}$ hingga sekitar $\mathrm{pH}$ isoelektrik kasein $(4,6)$ yang membuat penurunan daya ikat air (Ayuti et al., 2016). Saleh (2004) menambahkan bahwa semakin lama susu disimpan pada suhu rendah maka globulaglobula lemak bergerak ke permukaan dan membentuk suatu lapisan di permukaan susu.

Daya simpan suatu produk merupakan lamanya waktu simpan suatu produk dalam kondisi penyimpanan sesuai petunjuk penyimpanan. Menurut Codex Alimentarius (2004) menyatakan, waktu simpan merupakan suatu periode dimana produk dapat disimpan dan terhindar dari dampak perkembangan mikrobiologi dan kelayakan untuk dikonsumsi.

Beberapa penelitian telah dilakukan untuk mengetahui masa simpan yoghurt. Keamanan produk pangan termasuk yoghurt dapat dipengaruhi oleh senyawa-senyawa yang dihasilkan oleh bakteri asam laktat selama proses fermentasi. Menurut Ayuti et al (2016), suhu dan lama penyimpanan berpengaruh terhadap pertumbuhan lactobacillus casei, dimana dapat terjadi ketidakstabilan dan adanya perubahan karakteristik fisik susu fermentasi lactobacillus casei. Selain itu jenis susu juga dapat mempengaruhi yoghurt yang dihasilkan (Fatmawati et al., 2013).

Berdasarkan studi literatur yang telah dilakukan, kedua jenis susu (susu sapi dan susu kambing) yang dibuat menjadi yoghurt dapat difermentasi dalam waktu yang berbedabeda. Karakteristik yang dihasilkan juga berbeda dari satu hasil penelitian dengan lainnya.

Tingkat Penerimaan Panelis terhadap Yoghurt dengan Perlakuan Lama Fermentasi, Jenis Susu dan Lama Penyimpanan yang Berbeda (Tursina, Irfan, Sri Haryani)

Jurnal Ilmiah Mahasiswa Pertanian, Vol. 4, No. 3, 2019: 65-74 
Oleh karena itu dibutuhkan suatu penelitian untuk melihat pengaruh jenis susu yaitu susu sapi dan susu kambing dengan lama fermentasi yang berbeda terhadap karakteristik fisik dan kimia yoghurt selama penyimpanan.

\section{METODE PENELITIAN}

Penelitian ini dilaksanakan di Laboraturium Mikrobiologi Umum dan Laboratorium Uji Sensori Jurusan Teknologi Hasil Pertanian, Fakultas Pertanian, Universitas Syiah Kuala, Banda Aceh.

\section{Bahan dan Alat}

\section{MATERI DAN METODE}

Bahan yang digunakan dalam penelitian ini adalah susu bubuk full cream Frisian Flag, susu UHT merk Ultra Milk, susu kambing (diperoleh dari tempat peternakan kambing UD.Atjeh Livestock, Darussalam, Banda Aceh), starter yoghurt (Lactobacillus bulgaricus dan Streptococcus thermophillus) yang diperoleh dari Laboratorium Pengolahan Susu, Jurusan Peternakan, Fakultas Pertanian, Universitas Syiah Kuala dan gula pasir. Alat yang digunakan pada pembuatan yoghurt adalah kompor gas, panci, pengaduk, wadah plastik, laminar flow, gelas ukur, gelas plastik, alumunium foil, timbangan, thermometer, spatula, incubator, kertas wrap dan cup sealer.

\section{Metode Penelitian}

Metode penelitian menggunakan Rancangan Acak Kelompok (RAK) yang terdiri dari 3 faktor, faktor pertama yaitu lama fermentasi (F) yang terdiri dari 2 taraf, yaitu: $F 1=$ 10 jam, F2 = 16 jam. Faktor kedua yaitu jenis susu yang digunakan yang terdiri dari 2 taraf, yaitu: $\mathrm{S} 1$ = susu sapi dan $\mathrm{S} 2$ = susu kambing. Faktor ketiga yaitu lama penyimpanan yang terdiri dari 3 taraf, yaitu: $\mathrm{P} 1=0$ minggu, $\mathrm{P} 2=2$ minggu, $\mathrm{P} 3=4$ minggu. Kombinasi perlakuan dalam penelitian ini adalah : $2 \times 2 \times 3=12$ dengan menggunakan 3 (tiga) kali ulangan sehingga diperoleh 36 satuan percobaan.

\section{Analisis Data}

Untuk menguji pengaruh dari setiap faktor dan interaksi antar faktor terhadap parameter analisis, dilakukan analisis statistik dengan menggunakan ANOVA (Analysis of varians). Apabila perlakuan yang diberikan menunjukkan pengaruh terhadap parameter yang diuji, maka dilakukan uji Duncan.

\section{Proses Pembuatan Yoghurt}

\section{Penelitian Pendahuluan}

Penelitian pendahuluan bertujuan untuk mengetahui formulasi yang diperlukan dalam pembuatan yoghurt dengan metode Standarisasi Solid Non Fat (SNF). Nilai SNF merupakan hasil penjumlahan protein, mineral dan karbohidrat dari jenis susu yang digunakan dijadikan sebagai dasar perhitungan penentuan banyaknya susu bubuk dan gula yang ditambahkan. Penentuan kadar karbohidrat dilakukan dengan metode perhitungan by different.

\section{Penelitian Utama}

Sebanyak $1.625 \mathrm{ml}$ susu sapi dan susu kambing dimasukkan ke dalam panci, ditambahkan susu bubuk full cream dan gula pasir sesuai perhitungan standarisasi solid 
non fat (SNF). Lalu dipasteurisasi sampai suhu mencapai $85^{\circ} \mathrm{C}$ sambil diaduk selama 30 menit (Tamime dan Robinson, 2000). Selanjutnya dilakukan pendinginan sampai suhunya $40^{\circ} \mathrm{C}$ dengan direndam dalam air yang ditambahkan es batu dan diaduk. Inokulasi dengan campuran kultur bakteri Lactobacillus bulgaricus dan Streptococcus thermophillus perbandingan 1:1 sebanyak 3\% dari volume susu (Nirmagustina dan Wirawati, 2014). Kemudian masukkan ke dalam cup plastik $250 \mathrm{ml}$ dan ditutup dengan cup sealer yang diberi lapisan aluminium foil. Tahap selanjutnya inkubasi larutan pada suhu $40^{\circ} \mathrm{C}$ dengan lama inkubasi sesuai perlakuan yaitu 10 jam dan 16 jam. Hasilnya berupa Yoghurt disimpan sesuai perlakuan (0 minggu, 2 minggu dan 4 minggu) dan dianalisis. Analisis minggu ke-0 dilakukan setelah yoghurt didiamkan selama 3 hari pada lemari pendingin dengan suhu $3{ }^{\circ} \mathrm{C}$.

\section{HASIL DAN PEMBAHASAN}

\section{Warna}

Warna merupakan salah satu faktor penentu mutu dan tingkat penerimaan konsumen. Atribut warna menjadi salah satu faktor yang sering mendapat perhatian dari konsumen karena warna memberi kesan pertama terhadap komoditi pangan tersebut apakah akan disukai atau tidak. Warna sering dikatakan sebagai tanda pengenal dan daya tarik dari suatu produk oleh karena itu, warna memiliki peranan penting dalam parameter organoleptik (Tarwendah, 2017).

Umumnya yoghurt memiliki warna seperti bahan bakunya. Hasil uji hedonik warna diketahui bahwa perolehan kesukaan panelis berkisar 3,56 sampai 4,27 (suka) dengan perolehan nilai rerata 3,90. Hasil sidik ragam menunjukkan bahwa interaksi perlakuan jenis susu (S) dan lama penyimpanan $(\mathrm{P})$ berpengaruh sangat nyata $(\mathrm{P} \leq 0,01)$ terhadap penilaian warna yoghurt.

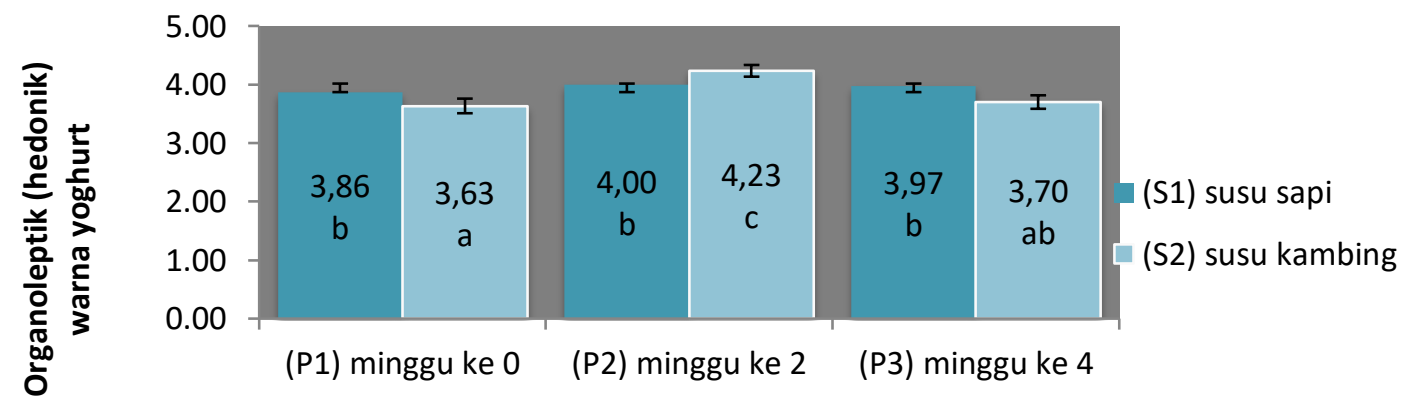

Lama Penyimpanan

Gambar 1. Pengaruh interaksi perlakuan jenis susu (S) dan lama penyimpanan (P) terhadap tingkat kesukaan warna yoghurt pada uji lanjut $\mathrm{DMRT}_{0,01}$ nilai yang diikuti oleh huruf yang sama tidak menunjukkan perbedaan yang nyata, $\mathrm{KK}=2,753 \%$.

Dari Gambar 1 dapat dilihat bahwa tingkat kesukaan panelis terhadap nilai uji organoleptik (hedonik) warna yoghurt susu kambing (S2) lebih tinggi pada lama penyimpanan minggu ke-2 dari yoghurt susu sapi (S1). Namun pada penyimpanan minggku ke-0 dan minggu ke-4 panelis lebih menyukai yoghurt susu sapi. Hasil tersebut menunjukkan bahwa panelis lebih menyukai warna yoghurt setalah lama penyimpanan minggu ke-2. Hal ini berkaitan dengan nilai viskositas dan $\mathrm{pH}$ yoghurt, dimana terjadi 
penerunan nilai $\mathrm{pH}$ selama penyimpanan yang diikuti oleh fase pertumbuhan bakteri asam laktat hingga pertumbuhan optimum. Chusniati dan Effendi (2008) menyatakan bahwa proses pembuatan yoghurt menyebabkan terjadinya penguraian laktosa menjadi galaktosa sebagai nutrisi pertumbuhan mikroba dan membentuk asam laktat sebagai hasil akhir. Penurunan $\mathrm{pH}$ disebabkan oleh asam laktat yang dihasilkan dan menimbulkan rasa asam. Kartikasari dan Nisa (2014) menambahkan, rendahnya nilai $\mathrm{pH}$ mencapai titik isoelektrik kasein $(4,6)$ menyebabkan keseimbangan kasein protein terganggu dan membentuk gumpalan koagulum sehingga terbentuk stuktur semi padat. Viskositas dapat mempengaruhi penampakan dan warna yoghurt, dimana yoghurt dengan nilai viskositas tinggi memiliki pantulan warna yang lebih pekat.

Selain interaksi antara jenis susu dan penyimpanan, interaksi lama fermentasi dan jenis susu juga memiliki pengaruh yang sangat nyata $(\mathrm{P} \leq 0,01)$ terhadap uji organoleptik (hedonik) warna yoghurt yang dihasilkan. Pengaruh perlakuan tersebut dapat dilihat pada Gambar 2.

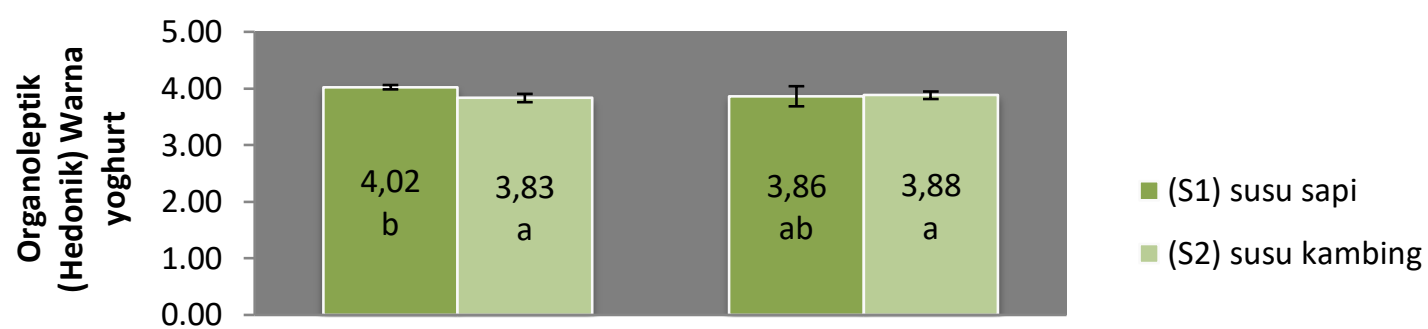

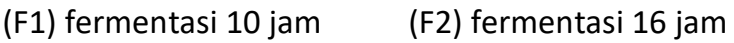

Lama fermentasi

Gambar 2. Pengaruh interaksi perlakuan lama fermentasi (F) dan jenis susu (S) terhadap tingkat kesukaan warna yoghurt pada uji lanjut $\mathrm{DMRT}_{0,01}$ nilai yang diikuti oleh huruf yang sama tidak menunjukkan perbedaan yang nyata, $\mathrm{KK}=2,753 \%$.

Dari Gambar 2 dapat dilihat bahwa secara umum tingkat kesukaan panelis terhadap nilai uji organoleptik (hedonik) warna yoghurt susu sapi (S1) lebih tinggi jika dibandingkan dengan yoghurt susu kambing (S2). Kemudian tingkat kesukaan panelis terhadap nilai uji organoleptik (hedonik) warna kedua yoghurt menurun dengan bertambahnya lama fermentasi. Yoghurt susu sapi fermentasi 10 jam (F1S1) memiliki tingkat kesukaan warna paling tinggi yaitu 4,02 (suka) sedangkan yoghurt susu kambing fermentasi 16 jam (F2S2) memiliki tingkat kesukaan lebih tinggi yaitu 3,88 (suka). Tidak ada perbendaan yang nyata antara perkuan tersebut. Hal ini dikarenakan yoghurt yang diteliti adalah yoghurt plain yaitu yoghurt tanpa penambahan buah, parasa atau pewarna sehingga ada kemiripan dari segi warna. Menurut Candraningastuti (2016) susu sapi dan susu kambing memiliki kemiripan warna, susu sapi tampak lebih kuning karena adanya kandungan betakaroten.

\section{Aroma}

Secara umum hasil penelitian organoleptik (hedonik) aroma yoghurt berkisar antara 2,87 (netral) sampai 3,70 (suka) dengan tingkat kesukaan rata-rata yaitu 3,37 (netral). Hasil sidik ragam menunjukkan bahwa interaksi perlakuan lama fermentasi $(F)$ dan jenis bahan 
baku (S) berpengaruh nyata $(\mathrm{P} \leq 0,05)$ terhadap penilaian aroma yoghurt. Pengaruh jenis susu terhadap aroma yoghurt dapat dilihat pada Gambar 3.

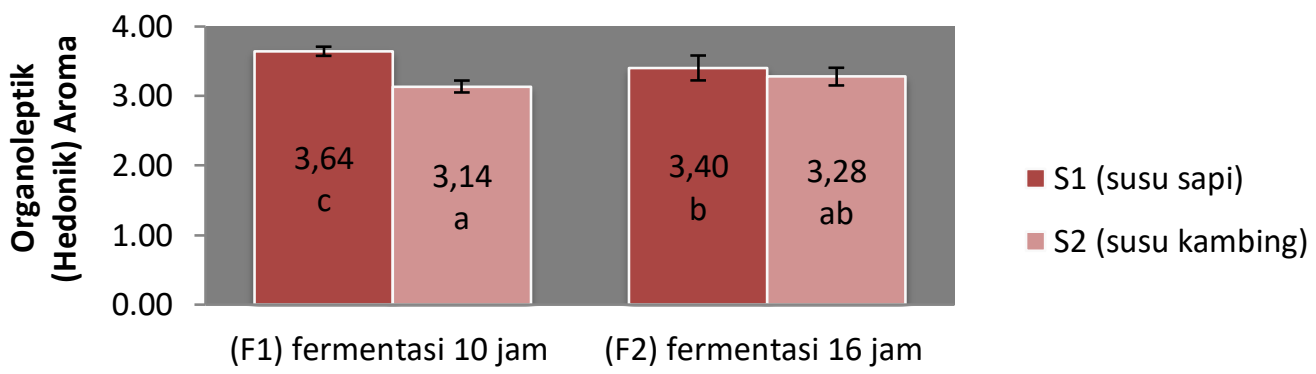

Lama Fermentasi

Gambar 3. Pengaruh interaksi perlakuan lama fermentasi (F) dan jenis susu (S) terhadap tingkat kesukaan aroma yoghurt pada uji lanjut $\mathrm{DMRT}_{0,05}$ nilai yang diikuti oleh huruf yang sama tidak menunjukkan perbedaan yang nyata, $\mathrm{KK}=6,615 \%$

Dapat dilihat dari Gambar 3, panelis lebih menyukai yoghurt berbahan dasar susu sapi (S1) dengan tingkat kesukaan 3,64 (suka) dibandingkan yoghurt berbahan dasar susu kambing 3,40 (netral). Selain itu terlihat bahwa yoghurt dari kedua jenis susu memiliki pengaruh yang sama yaitu mengalami penuruan tingkat kesukaan panelis dengan bertambahnya lama fermentasi. Diduga hal tersebut dipengaruhi oleh aroma dasar bahan baku, susu kambing memiliki aroma yang kurang disukai panelis berupa prengus yaitu aroma khas susu kambing. Menurut Candraningastuti (2016), aroma prengus pada yoghurt susu kambing dapat diturunkan dengan cara fermentasi. Yoghurt yang di fermentasi selama 3, 6 dan 9 jam memiliki tingkat aroma prengus yang berbeda. Aroma prengus terendah didapat pada yoghurt fermentasi 9 jam.

Legowo et al (2006) menyatakan aroma prengus dipengaruhi oleh kandungan asam lemak kaprilat dan asam lemak laurat dalam susu kambing yang belum dipecah oleh inokulasi mikrobia sehingga asam lemak tersebut berpengaruh terhadap munculnya rasa dan aroma prengus pada susu kambing. Maliza (2018) menambahkan cara lain mengurangi aroma khas pada susu adalah dengan penambahan susu skim. Selama proses fermentasi, pertumbuhan bakteri didukung oleh penambahan susu skim sebagai sumber substrat utama. Menurut Layadi et al (2009) asam laktat yang dihasilkan oleh L. bulgaricus dan $S$. Thermophilus memberikan pengaruh terhadap aroma. Semakin tinggi kandungan asam maka aroma asam khas yoghurt akan semakin kuat. Hal ini juga dipengaruhi oleh lama fermentasi, dimana penambahan waktu fermentasi menyebabkan penurunan nilai $\mathrm{pH}$ yang berpengaruh pada aroma. Layadi et all (2009) melaporkan dalam penelitiannya bahwa aroma soyghurt di pengaruhi oleh asam laktat hasil produksi bakteri yang berperan yaitu menghasilkan aroma khas yoghurt. Produksi asam laktat berkaitan erat dengan nilai $\mathrm{pH}$ dan populasi bakteri asam laktat.

\section{Rasa}

Rasa menjadi salah atribut sensori yang sangat mempengaruhi tingkat penerimaan panelis terhadap suatu makanan. Hasil penilaian hedonik rasa memiliki nilai rata-rata 3,33 (netral) dengan nilai tertinggi 3,54 (suka) dan nilai terendah yaitu 3,11 (netral). Hasil sidik ragam menunjukkan perlakuan jenis susu $(\mathrm{S})$ memberikan pengaruh sangat nyata $(\mathrm{P} \leq 0,01)$ 
terhadap penerimaan panelis. Pengaruh jenis susu (S) terhadap penilaian hedonik rasa yoghurt dapat dilihat pada Gambar 4.

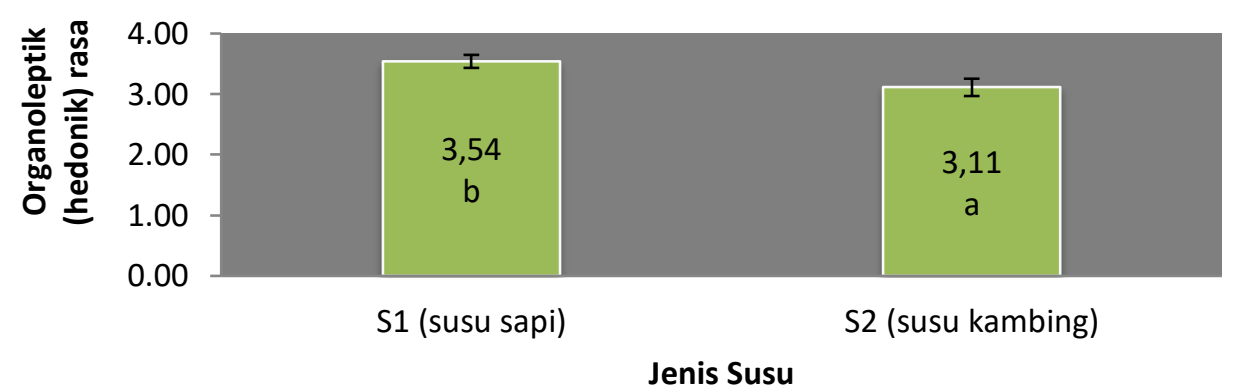

Gambar 4. Pengaruh jenis susu (S) terhadap tingkat kesukaan rasa yoghurt pada uji lanjut DMRT $_{0,01}$ nilai yang diikuti oleh huruf yang sama tidak menunjukkan perbedaan yang nyata, $\mathrm{KK}=8,841 \%$

Hasil uji DMRT 0,01 (Gambar 4) menunjukkan bahwa panelis lebih menyukai yoghurt susu sapi yaitu 3,54 (suka) jika dibandingkan dengan yoghurt susu kambing yang memiliki tingkat kesukaan panelis yang lebih rendah yaitu 3,11 (netral). Tingkat kesukaan panelis terhadap rasa dipengaruhi oleh kandungan asam pada yoghurt, dibuktikan dengan perbedaan nilai $\mathrm{pH}$ terhadap kedua jenis yoghurt, dimana $\mathrm{pH}$ susu kambing lebih rendah daripada $\mathrm{pH}$ susu sapi. Hal ini menyebabkan panelis lebih menyukai rasa yoghurt berbahan baku susu sapi. Menurut Agustina et al (2015) penurunan nilai pH diakibatkan oleh aktivitas mikroba yang merubah unsur kimia pada komponen gula menjadi asam. Flavor yang terbentuk selama fermentasi yoghurt memberikan pengaruh terhadap kontribusi tingkat kesukaan responden terhadap rasa. Layadi et al (2009) menuliskan dalam penelitiannya bahwa rasa yoghurt dipengaruhi oleh bakteri yang berperan dalam pembuatannya yaitu Lactobacillus bulgaricus dan Streptococcus thermophilus. Namun dalam hal ini Streptococcus thermophilus lebih produktif dalam menghasilkan rasa asam.

Selain itu perlakuan jenis susu (S), perlakuan lama penyimpanan (P) juga berpengaruh sangat nyata $(\mathrm{P} \leq 0,01)$ terhadap nilai uji organoleptik (hedonik) rasa pada yoghurt. Pengaruh perlakuan lama penyimpanan disajikan pada Gambar 5.

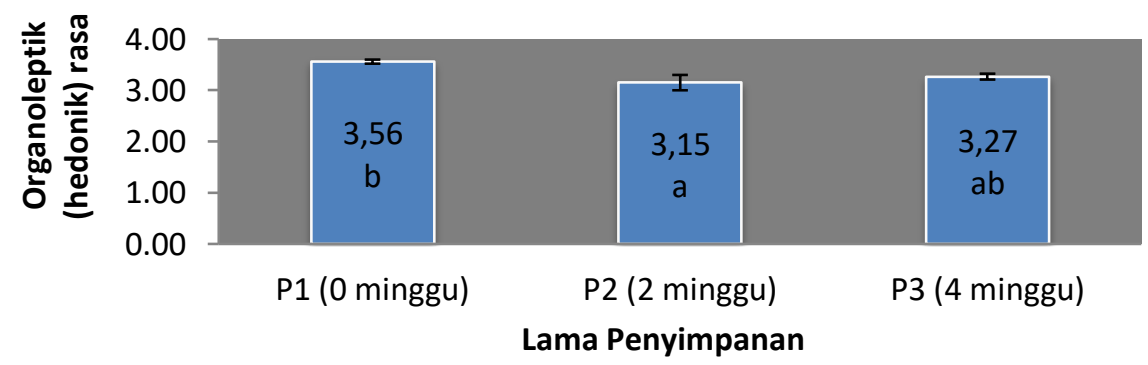

Gambar 5. Pengaruh lama penyimpanan (P) terhadap tingkat kesukaan rasa yoghurt pada uji lanjut $\mathrm{DMRT}_{0,01}$ nilai yang diikuti oleh huruf yang sama tidak menunjukkan perbedaan yang nyata, $\mathrm{KK}=8,841 \%$.

Hasil uji DMRT $_{0,01}$ (Gambar 5) menunjukkan bahwa tingkat kesukaan panelis terhadap yoghurt penyimpanan minggu ke-0 (P1) berbeda dengan perlakuan yoghurt penyimpanan minggu ke-2 (P2). Terlihat bahwa tingkat kesukaan panelis terhadap rasa mengalami penurunan dengan bertambanya lama penyimpanan. Diduga hal ini berkaitan 
dengan nilai $\mathrm{pH}$ selama penyimpanan, dimana selama penyimpanan terjadi peningkatan nilai $\mathrm{pH}$ sebagai hasil aktifitas mikobia sehingga menyebabkan peningkatan rasa asam pada yoghurt. Layadi et al (2009) menyatakan bahwa semakin lama waktu penyimpanan jumlah koloni akan semakin meningkat hingga jumblah maksimum yaitu waktu simpan terbaik. Semakin lama yoghurt disimpan maka akan semakin asam, hal ini dapat mempengaruhi tingkat kesukaan panelis.

\section{Tekstur}

Umumnya yoghurt memiliki tekstur semi padat yaitu bertekstur tidak terlalu cair dan tidak terlalu kental. Hasil uji hedonik tekstur berkisar antara 3,00 (netral) sampai 3,83 (suka) dengan perolehan rerata 3,32 (netral). Hasil sidik ragam membuktikan perlakuan jenis susu ( $\mathrm{S})$ berpengaruh nyata $(\mathrm{P} \leq 0,05)$ terhadap tingkat penerimaan responden terhadap tekstur yoghurt. Namun, perlakuan lama penyimpanan $(\mathrm{P})$ berpengaruh sangat nyata $(\mathrm{P} \leq 0,01)$ terhadap tingkat penerimaan responden terhadap tekstur yoghurt. Pengaruh perlakuan jenis susu dan lama penyimpanan disajikan pada Gambar 6 dan 7.

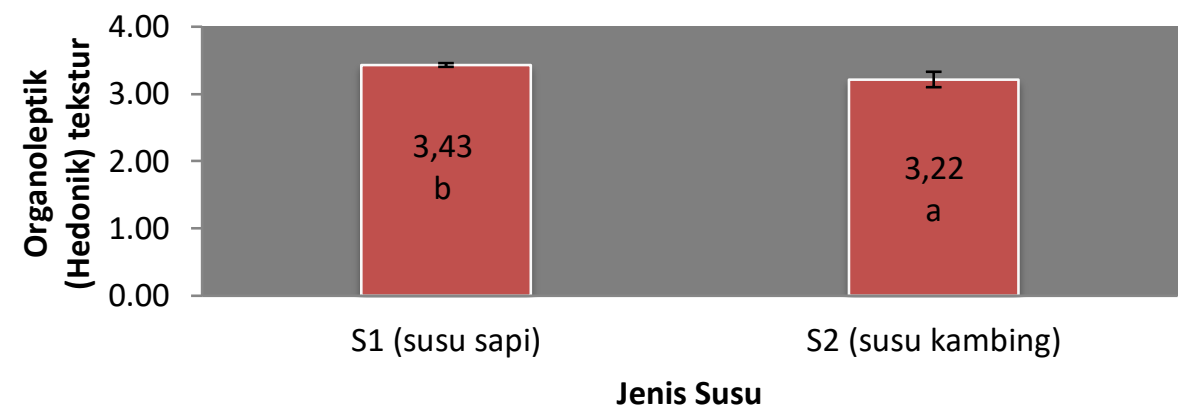

Gambar 6. Pengaruh jenis susu (S) terhadap tingkat kesukaan tekstur yoghurt pada uji lanjut DMRT $_{0,05}$ nilai yang diikuti oleh huruf yang sama tidak menunjukkan perbedaan yang nyata, $\mathrm{KK}=7,678 \%$.

Berdasarkan Gambar 6, secara umum panelis lebih menyukai tekstur yoghurt susu sapi dibandingkan yoghurt susu kambing. Hasil uji lanjut $\mathrm{DMRT}_{0,05}$ menunjukkan bahwa perlakuan yoghurt susu sapi berbeda dengan yoghurt susu kambing. Diduga tingkat kesukaan panelis terhadap tekstur berkaitan dengan viscositas dan protein yoghurt yang dihasilkan. Pemecahan asam-asam organik selama fermentasi mengakibatkan protein pada bahan baku terdenaturasi membentuk suatu gumpalan dan meningkatkan nilai viskositas. Semakin tinggi kandungan bakteri asam laktat maka nilai viskositas akan semakin tinggi dan tekstur produk semakin kental. Maliza (2018) mengungkapkan hal yang serupa, dimana tingkat kesukaan panelis terhadap tekstur soyghurt dipengaruhi oleh viskositas dan total asam.

Berdasarkan Gambar 7, secara umum tingkat kesukaan panelis menurun secara signifikan pada waktu penyimpanan minggu ke-4. Hasil uji lanjut $\mathrm{DMRT}_{0,01}$ menunjukkan bahwa perlakuan lama penyimpanan minggu ke-0 (P1) berbeda dengan yoghurt dengan lama penyimpanan minggu ke-4 (P3). Diduga tingkat kesukaan panelis terhadap tekstur berkaitan dengan nilai $\mathrm{pH}$ dan total asam yoghurt yang dihasilkan. Turunya nilai $\mathrm{pH}$ diikuti dengan semakin tingginya populasi mikroba selama penyimpanan hingga pertumbuhan optimum yaitu waktu terbaik penyimpanan. Hal ini juga menyebabkan total asam yang semakin meningkat dengan bertambahnya waktu penyimpanan. Layadi et al (2009) menyatakan hal serupa, penambahan waktu simpan akan meningkatkan jumlah koloni 
hingga jumlah maksimum (waktu simpan terbaik), total asam meningkat dan $\mathrm{pH}$ menurun menghasilkan aroma khas yoghurt semakin kuat. Yoghurt dengan aroma asam lebih kuat memiliki tekstur atau viskositas yang encer dibandingkan yoghurt beraroma manis. Helferich dan Westhoff (1980) menambahkan, tekstur yang lembut serta flavor yang disukai dihasilkan selama proses fermentasi. Suasana asam ( $\mathrm{pH}$ rendah) yaitu pada $\mathrm{pH}$ isoelektrik $(\mathrm{pH}=4,6)$ membuat keseimbangan kasein terganggu membentuk kougulan berupa susu semi padat.

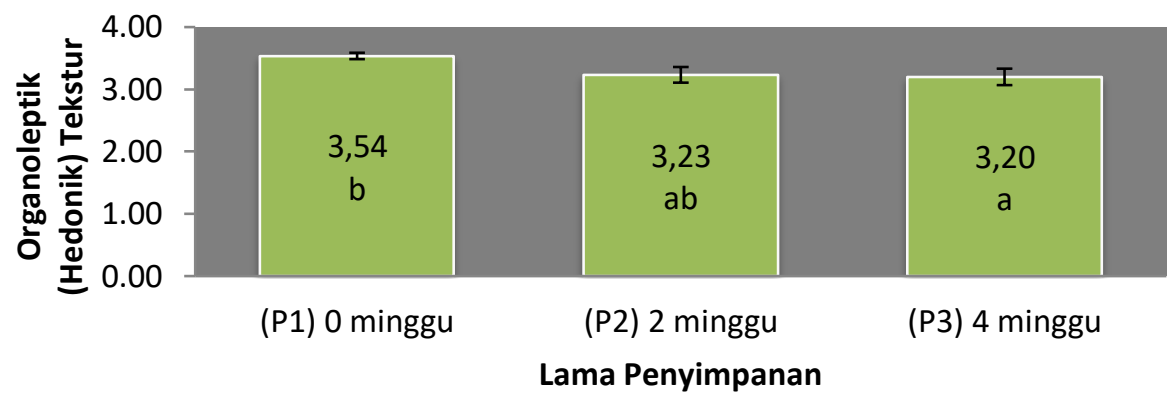

Gambar 7. Pengaruh lama penyimpanan (P) terhadap tingkat kesukaan tekstur yoghurt pada uji lanjut $\mathrm{DMRT}_{0,01}$ nilai yang diikuti oleh huruf yang sama tidak menunjukkan perbedaan yang nyata, $\mathrm{KK}=7,678 \%$.

\section{KESIMPULAN DAN SARAN}

\section{Kesimpulan}

Secara umum panelis masih menyukai yoghurt hingga lama penyimpanan minggu ke-4. Hasil uji organoleptik (hedonik) menunjukkan bahwa panelis lebih menyukai yoghurt dengan perlakuan jenis susu sapi fermentasi 10 jam dengan lama penyimpanan minggu ke0 .

\section{Saran}

Perlu dilakukan penelitian lanjut tentang penambahan waktu penyimpanan menggunakan metode arrhenius terhadap kualitas yoghurt, membuat yoghurt dengan penambahan buah atau bahan pangan lokal.

\section{DAFTAR PUSTAKA}

Agustina, Y., Kartika, R dan Panggabean, A. S. 2015. Pengaruh Variasi Waktu Fermentasi Terhadap Kadar Laktosa, Lemak, pH dan Keasaman Pada Susu Sapi Yang Difermentasi Menjadi Yogurt. Jurnal Kimia Mulawarman. Vol 12. No 2

Ayuti, S. A., Nurlliana., Yurliasni., Sugito dan Darmawi. 2016. Dinamika Pertumbuhan Lactobacillus casei dan Karakteristik Susu Fermentasi Berdasarkan Suhu dan Lama Penyimpanan. Jurnal Agripet. Vol 16. No 1.

Candraningtyastuti, D. 2016. Yoghurt Susu Kambing Dengan Penambahan Jus Jus Daun Pandan (Pandanus amaryllifolius Roxb) dan Waktu Fermentasi. Skripsi. Universitas Sanata Dharma, Yogyakarta.

Codex Alimentarius Comission. 2004. CAC/RCP 57-2004 : Code of Hygienic Practice For Milk and Milk Products. FAO and WHO, Rome. Didalam. Budiyono, H. 2009. 
Analisis Daya Simpan Produk Susu Pasteurisasi Berdasarkan Kualitas Bahan Baku Mutu Susu. Jurnal Paradigma. Vol 5. No 2. Hal 198-211

Effendi, M.H., S. Hartini dan A.M. Lusiastuti. 2009. Peningkatan Kualitas Yoghurt Dari Susu Kambing Dengan Penambahan Bubuk Susu Skim dan Pengaturan Suhu Pemeraman. J. Penelit. Med. Eksakta. Vol 8, No. 3

Fatmawati, U., Prasetyo, F.I., T.A, Supia, M dan Utami, N.A. 2013. Karakteristik Yogurt Yang Terbuat Dari Berbagai Jenis Susu Dengan Penambahan Kultur Campuran lactobacillus bulgaricus dan streptococcus thermophillu. Bioedukasi. Vol 2. No 6. Hal 1-9

Hafsah dan Astriana. 2012. Pengaruh Variasi Strater Terhadap Kualitas Yogurt Susu Sapi. Jurnal Bionature. Volume 13. Nomor 2. Hlm 96-102.

Halferich, W. And Westhoff. 1980. All about yoghurt. Prentice-Hall Inc. Englewood Cliffs, New Jersey.

Kartikasari, D.A dan Nisa, F. C. 2014. Pengaruh Penambahan Sari Buah Sirsak dan Lama Fermentasi Terhadap Karakterisktik Fisik dan Kimia Yoghurt. Jurnal Pangan Dan Agroindustri. Vol 2. No 4. Hal 239-248

Layadi, N., Sedyandini, P., Aylianawati dan Soetaredjo, F.E. 2009. Pengaruh Waktu Simpan Terhadap Kualitas Soyghurt Dengan Penambahan Gula dan Stabilizer. Widya Teknik. Vol 8. No 1. Hal 1-11

Legowo, A. N., A. N. Al-Baari., M. Adnan dan U. Santosa. 2006. Intensitas Aroma "Prengus" dan Deteksi Asam Lemak Pada Susu Kambing. Jurnal Indonesia Tropical Animal Agricultural. Vol 34. No 4. Hal 276-280

Maliza, N. O. 2018. Pembuatan Minuman Probiotik Fruit Soygurt Dengan Penambahan Puree Buah Jamblang (Syzygium cumini). Skripsi. Teknologi Hasil Pertanian Unsyiah. Unsyiah, Banda Aceh

Saleh, E. 2004. Dasar Pengolahan Susu dan Hasil Ikutan Ternak. USU. Digital Library, Sumatera Utara

Susilowati. 2012. Pembuatan Yoghurt Susu Sapi Dengan Bantuan Mikroorganisme Dalam Plain Yoghurt Menggunakan Alat Fermentor. Skripsi. Program Diploma III Teknik Kimia. Universitas Diponegoro. Semarang.

Tarwendah, I.P. 2017. Studi Komparasi Atribut Sensoris dan Kesadaran Merek Produk Pangan. Jurnal Pangan dan Agroindustri, Vol.5, No.2, Hal.66-73.

Zakaria, Y., Yurliasni, Delima, M dan Diana, E. 2013. Analisa Keasaman dan Total Bakteri Asam Laktat Yogurt Akibat Bahan Baku dan Persentase Lactobacillus casei yang Berbeda. Jurnal Agripet. Vol 13. No 2. 